УДК 658.5:658.26

DOI: https://doi.org/10.37320/2415-3583/12.17

Дегтярьова O.O.

кандидат економічних наук, доцент,

Одеський начіональний економічний університет ORCID: https://orcid.org/0000-0003-1276-334X

\title{
КЛАСИФІКАЦІЯ ТА АНАЛІЗ СУЧАСНИХ ІНСТРУМЕНТІВ КОНТРОЛІНГУ ДЛЯ ПІДВИЩЕННЯ ЕФЕКТИВНОСТІ ВИРОБНИЧИХ ЕНЕРГОСИСТЕМ
}

У статті досліджено функиіонально-інструментальні аспекти новітнього напряму розвитку концепціі контролінгу - енергетичного контролінгу. Його особливістю є поєднання деяких контрольно-технічних із традиційними фінансово-економічними інструментами в межсах виконання функцій контролінгу. Згідно з проведеною класифікацією системно згенеровано та описано інструментарій енергетичного контролінгу за ознаками иілі використання та очікуваного результату. На основі аналізу застосування інструментів енергетичного контролінгу в господарчій діяльності низки промислових підприємств було зроблено висновок щяодо виконання його функиій. Крім того, було виявлено потенціал підвищення енергоефективності досліджуваних підприємств економічними методами за рахунок розширення інструментальної бази, щчо використовуватиме енергетична служба.

Ключові слова: енергетичний контролінг, функиї контролінгу, інструменти контролінгу, енергоефективність, промислові підприємства.

Постановка проблеми. Проблема підвищення енергоефективності гостро стоїть перед економікою України. Постійне зростання цін на енергоносії, необхідність як житлового, так і промислового енергозбереження спонукають підприємства шукати новітні шляхи управління власними виробничими енергосистемами. Впровадження технічних заходів та інновацій - це не єдиний шлях підвищення енергоефективності, існують також економічні інструменти, які здатні суттєво удосконалити роботу енергетичного господарства і тим самим підвищити його ефективність. Для цього необхідно забезпечити прозорість енергетичних процесів, оптимально використовувати енергетичні ресурси, а також системно застосовувати технічні та економічні інновації.

Прозорість, оптимальність, системність, достовірність, своєчасність та узгодженість - фундаментальні принципи концепції контролінгу. Тому роз-ширення концептуальних засад та інструментарію контролінгу на виробничі енергосистеми спроможне внести вагомий вклад в управління енергоефекти-вністю, енергозбереженням і взагалі суттєво поліпшити роботу енергетичної служби.

Аналіз останніх досліджень і публікацій. В Україні питання управління виробничими енергосистемами розглядаються переважно у ракурсі енергетичного менеджменту. Деякі автори досліджували також його функції та інструменти, але 3 огляду або на енергозабезпечення (Ю.В. Дзядикевич, М.В. Буряк, Р.I. Розум [1, с. 58-70]), або на міжнародний стандарт ISO 50001:2011 «Energy management systems - Requirements with guidance for use», "Системи енергоменеджменту - вимоги та керівництво щодо використання» (С.П. Денисюк, О.В. Бориченко [2, с. 12-13]). Дослідження І.М. Сотник та Л.А. Кулик показало, що енергоменджменту в сучасному вигляді не досить для вирішення всіх завдань виробничих енергосистем, особливо коли йдеться про інвестиції в енергоефективність, енергозбереження тощо, тому потрібні додаткові консалтингові послуги та відповідний інструментарій [3, с. 213].

Західні економісти, переважно німецькі, які вже досліджують теорію та практику застосування контр- олінгу в енергетичній сфері, вважають енергетичний контролінг таким, що підвищує прозорість, керованість i, відповідно, ефективність виробничих енергосистем. Р. Гляйх та М. Шульце зробили першу спробу класифікувати інструменти енергетичного контролінгу за виконуваними функціями i дійшли висновку, що його інструментарій має включати в себе не тільки притаманні контролінгу фінансово-економічні інструменти, але й деякі техніко-економічні інструменти 3 енергетичного управління [5, с. 73].

Метою статті $\epsilon$ науково-методичне обгрунтування інструментальної бази енергетичного контролінгу, під яким розуміється мультифункціональна система досягнення енергетичних цілей підприємства, яка кількісно відображається в необхідних рівнях енергоефективності, енергозбереження. Для досягнення поставленої мети необхідно виконати такі завдання:

- проаналізувати сучасні інструменти контролінгу щодо їх застосування в енергетичній сфері підприємства,

- класифікувати їх за функціями контролінгу,

- дослідити впровадження інструментів енергетичного контролінгу на промислових підприємствах України.

Виклад основного матеріалу. Функціональне наповнення контролінгу визначається поставленими перед організацією цілями і включає в себе ті види діяльності, які забезпечують досягнення цих цілей. Однією $з$ основних причин виникнення й розвитку концепції контролінгу стала необхідність у системній інтеграції різноманітних аспектів фінансово-господарської діяльності. Контролінг забезпечує методичну й інструментальну базу для підтримки основних функцій управління, але має і власне функціональне наповнення: планування, координування, інформаційне забезпечення, контроль та консультування.

Для виконання означених функцій енергетичному контролінгу потрібен відповідний інструментарій. Відбір та класифікацію інструментів для виконання кожної функції було проведено серед низки традиційних фінансово-економічних інструментів контролінгу, а також деяких контрольно-технічних інструментів 
енергетичного менеджменту за ознаками очікуваного результату та мети використання.

1. Енергетичний баланс підприсмства - відноситься до техніко-економічних інструментів енергетичного контролінгу, широко застосовується в енергетичному менеджменті. Він дає можливість оцінити стан енергетичного господарства на підприємстві i $є$ відправною точкою енергетичного планування. Зазвичай енергетичний баланс складається після візуалізації енергетичних потоків на підприємстві і згідно 3 першим законом термодинаміки, тобто обчислюється для підприємства, цеху або групи обладнання з урахуванням їхньої потреби в енергії, втрат у мережах та ступеня впливу під час перетворення енергії. Але для досягнення цілей постійного покращення, як того вимагає міжнародний стандарт ISO 50001:2011, цьому інструменту необхідно додати ще систему заохочення за енергозбереження понад норми та інші додаткові опції.

2. Картина енергетичних потоків є фундаментальною основою активного енергетичного менеджменту, яка показує спрямування енергоносіїв, місця їхнього перетворення та споживання, але не дає відповіді на питання, у якій кількості переміщуються потоки енергії всередині підприємства. Для цілей енергетичного контролінгу цього недостатньо. Потрібне наглядне відображення місць споживання енергоносіїв за видами, необхідності їх та місця їхнього перетворення, процесів або обладнання, до якого енергоносії доставляються безпосередньо або в перетвореному вигляді, можливості використання енергоносіїв, що залишилися після виконання процесів або споживання обладнанням, можливості продажу перетворених або створених енергоносіїв. Тому для виконання функції планування як картину енергетичних потоків варто використовувати diazpaмy Санкей (англ. Sankey Diagram) - візуалізаційний інструмент, що дає уяву також і про обсяги енергетичних потоків. Перевагою діаграми Санкей є досить просте й наглядне графічне відображення складних взаємозв'язків в енергетичній системі підприємства.

3. Графіки енергетичного навантаження показують режим споживання енергії у часі. Вони є основою енергетичних балансів, розрахунку необхідної потужності джерел енергії та оптимального режиму роботи обладнання, рекомендацій 3 регулювання та визначення умов роботи енергетичних мереж та міжсистемних зв'язків. Складання таких графіків необхідне як для планування, так і для керування енергетичним навантаженням.

4. Портфельний аналіз широко застосовується в контролінгу для стратегічного планування та аналізу довгострокових стратегій. Енергетичні портфелі підприємства можуть складатися з портфеля споживання, портфеля енергетичних інвестиційних проектів, портфеля стратегічних енергетичних одиниць тощо. Портфельний аналіз в енергетичному контролінгу дозволить поліпшити як якість довгострокових управлінських рішень щодо виконання енергетичної стратегії, так i взагалі стратегічне планування на підприємстві. Наявні матричні моделі портфельного аналізу (БКГ, МакКинсі, АДЛ та інші) можуть бути успішно адаптовані під потреби енергетичного планування та аналізу.
5. Аналіз енергетичного ринку є важливим під час енергетичного планування, бо дає уяву про взаємодію гравців ринку, динаміку цін на енергоносіі, взаємодію продавців та споживачів енергетичних ресурсів, регуляторну політику в країні та за ії межами тощо. Енергетичний контролінг використовує результати проведеного аналізу під час складання енергетичного балансу та власного енергетичного портфеля, пошуку постачальників, енергоефективного обладнання та технологій, складання власної енергетичної стратегії.

6. Бенчмаркінг останнім часом широко застосовується в Україні для порівняння та перевтілення найліпших практик різних підприємств або ведучих підрозділів всередині власного підприємства. Він викликає неабиякий науковий і практичний інтерес, бо з найменшими витратами за його допомогою можна отримати вагомий результат у тому числі і в енергетичній сфері. Бенчмаркінг $€$ інструментом стратегічного контролінгу, а його кінцевою ціллю в енергетичному контролінгу - покращення стану енергоефективності на підприємстві. Об'єктом покращення можуть бути не тільки конкретні величини енергетичних витрат або безпосередньо показники енергоефективності, але й окремі енергетичні процеси, використання енергоресурсів за видами, енергетичні стратегії, або ж взагалі система енергоменеджменту на підприємстві.

7. Аналіз та управління ризиками має місце як в концептуальному тлумаченні, так і в практичному застосуванні функції енергетичного планування. Певний ступінь невизначеності, що супроводжує кожне управлінське рішення та підвищується за віддалення горизонту планування, великою мірою характерний і для енергетичних питань. Більше того, західні дослідники виділяють тут дві групи ризиків, що відрізняються як за своєю економічною сутністю, так і за підходами до їхнього управління: 1) інвестиційні ризики [4, с. 467] та 2) виробничі ризики [6, с. 134]. Але обидві групи потребують аналізу та дій із метою їх пом'якшення. Тобто вже на стадії планування має бути врахованим ризик того, що, з одного боку, очікувані результати не будуть досягнуті, а з іншого - будуть передбачені кроки $з$ попередження несприятливих ситуацій.

8. Інвестиційні розрахунки та обгрунтування інвестиційних рішень традиційно належать до функції планування стратегічного контролінгу. Особливості інвестиційних розрахунків в енергетичній сфері пов'язані з:

- оцінкою ефективності інвестиційних проектів через призму майбутніх енергетичних витрат та очікуваної величини енергозбереження;

- браком інформації та досвіду інвестування в сучасні енергетичні технології, оскільки в енергетичній сфері відбуваються постійний технологічний прогрес та соціально-економічна обізнаність суспільства;

- довгостроковим характером інвестиційних проектів і проблемами з інтеграцією в процеси оперативного планування, обчисленням амортизаційних відрахувань тощо.

9. Метод морфологічного аналізу, який був запропонований швейцарським астрофізиком Фріцем Цвікі (1898-1974), допомагає розглядати різні можливі рішення проблеми, розбиваючи їі на окремі атрибути та комбінуючи їхні можливі реалізації. В економіці морфологічний аналіз застосовується під час прийняття 
тих управлінських рішень, для яких властиве генерування щодо великої кількості варіантів рішень, подальшої систематизації вибраних варіантів та їх аналізу.

У межах реалізації функції планування енергетичного контролінгу морфологічний аналіз застосовується під час розроблення енергетичної стратегії. Морфологічні матриці можуть бути побудовані для аналізу чинників стратегічного впливу (наприклад, маркетингового сегменту, вибраної конкурентної стратегії, організаційної структури підприємства, ризикових преференцій тощо) або для аналізу основних параметрів енергетичної стратегії (наприклад, постачання енергіï, рівня енергоефективності тощо) чи енергетичного потенціалу [4, с. 785, 790].

10. Діаграма Ганта (англ. Gantt chart) широко застосовується в управлінні проектами. Вперше вона була запропонована у 1910 р. американським ученим Генрі Лоуренсом Ганттом (Henry Lawrence Gantt) під час будівництва суден у вигляді графіка для управління низкою інженерів та їхніми завданнями, які мали бути виконаними протягом певного часу та iз застосуванням певних ресурсів. В енергетичному контролінгу діаграма Ганта використовується для регулювання та відповідної оптимізації енергетичних процесів на підприємстві.

11. Управління за відхиленнями є контролінговим інструментом для виявлення та аналізу відхилень від плану, а також проміжного координування виконання проектів, робіт, виробничого процесу. У межах функції координування енергетичного контролінгу акцент робиться на аналізі ключових проміжних результатів (англ. milestone analysis) та підготовці проміжних звітів, які ілюструють ступінь досягнення встановлених milestones. «Milestone» при цьому розуміють як своєрідні ворота, через досягнення яких стає можливим перехід у наступну робочу фазу [4, с. 249]. Таким чином, за допомогою проміжних звітів координується реалізація ще не повністю виконаної задачі.

12. Найпростіший аналіз динаміки енергетичних витрат полягає у зіставленні поточних величин витрат з їхніми величинами за попередні періоди. Зібрані дані надаються у зручному для аналізу вигляді - графіків або таблиць. Більш сучасним є аналіз трендів енергетичних витрат. Аналіз динаміки енергетичних витрат може бути довгостроковим і короткостроковим. Тобто, з одного боку, він має бути спрямованим у майбутнє, бо його результати можуть використовуватися для постановки цілей і стратегічного планування, а 3 іншого боку - на координування реально досягнутих результатів у підрозділах підприємства 3 прицілом на загальну мету енергоефективності.

13. Енергетичний облік охоплює збір кількісних даних про споживання енергії для наступної обробки, підготовку й оцінку зібраної інформації (наприклад, за носіями енергії, за певний період, за підрозділами підприємства, за окремими споживачами). За своєю сутністю він схожий на моніторинг, але несе в собі суто інформаційне наповнення без технічної і контрольно-аналітичної складових частин. Тому вид, зміст і обсяг енергетичного обліку встановлюється залежно від інформаційних потреб підприємства.

14. Розрахунок енергетичних витрат виконується за встановленими на підприємстві моделями розра- хунку витрат на основі даних енергетичного обліку. В енергетичному контролінгу, крім безпосереднього визначення величини енергетичних витрат, розрахунок енергетичних витрат сприяє виявленню економічно неефективних енергетичних ланок в організації, $\epsilon$ необхідним складником під час визначення рівня енергоефективності, використовується під час обгрунтування інвестиційних рішень та слугує інформаційною базою для техніко-економічних досліджень. 3 огляду на вагомий інформаційний контент, що несе в собі розрахунок енергетичних витрат, логічно віднести його до інформаційної функції.

15. Внутрішньовиробничий енергетичний розрахунок напряму пов'язаний із розрахунком енергетичних витрат. При цьому вся первинна енергія, яка постачається на підприємство, а також усі види вторинної енергії обчислюються за окремими підрозділами підприємства у вартісному та/або натуральному вираженні. Підрозділи в розрахунках розглядаються як внутрішні споживачі енергії. Внутрішньовиробничий енергетичний розрахунок відноситься до інформаційної функції енергетичного контролінгу, бо результати розрахунків надають важливу інформацію для управління витратами (особливо щодо видів та місць виникнення витрат), інтегруються до загальної інформаційної бази підприємства, а за необхідності - формують окрему енергетичну інформаційну систему.

16. Розрахунок витрат за прочесами або розрахунок собівартості за видами діяльності (англ. ActivityBased-Costing) тісно пов'язаний із процесним підходом, тому для опису бізнес-процесів рекомендується використовувати програмні продукти. Енергетичні витрати часто відносять до накладних витрат, і тому ускладнюється внутрішньогосподарський розрахунок споживання енергії, і некоректно відображаються витрати енергії в собівартості кінцевого продукту. Процесо-орієнтований розрахунок надає більш достовірну інформацію щодо носіїв енергетичних витрат (англ. energy cost drivers), місць виникнення енергетичних витрат та саме процесів, які пов'язані з придбанням та використанням енергетичних ресурсів.

17. Складання звітів бачиться багатьма західними дослідниками концепції контролінгу як одне 3 його ключових призначень. Крім того, згідно з міжнародним стандартом ISO 50001:2011, документування досягнень, управління записами і складання звітів 3 енергоефективності $\epsilon$ обов'язковою вимогою сертифікованого енергоменеджменту. Тому енергетична звітність є елементом інформаційної функції енергетичного контролінгу. Контролінговий звіт про загальний стан енергетичної діяльності підприємства - це стандартний документ, в якому представлені результати аналітичної роботи, висновки й пропозиції щодо споживання, а можливо, і власного виробництва енергії, (наприклад, з альтернативних джерел), енергозбереження, енергоефективності та енергобезпеки. Він $є$ одним з основних джерел релевантної інформації для прийняття управлінських рішень в енергетичній сфері. Крім звіту про загальний стан, можуть бути складені стандартні, довідкові та звіти про відхилення фактичних результатів від запланованих. Якість внутрішньої системи звітності має бути направленою передусім на відповідну реакцію користувачів інформації. Таким 
чином, енергетична звітність формує інформаційну базу контролінгу і наступних управлінських рішень в енергетичній сфері.

18. Спеціальні програмні продукти в енергетичній сфері підприємства розробляються для: 1) поточного моніторингу; 2) оперування базами даних; 3) бізнесової аналітики (business intelligence). Відповідно, їхне призначення - це збір, систематизація та обробка інформації. Для багаторівневої інформаційної підтримки управлінських рішень в енергетичній сфері незалежні групи вчених пропонують перетворити інструмент «Management Cockpit» під apхітектуру і для цілей енергетичного контролінгу $[5$, c. 73]. Вони назвали цей інноваційний інструмент «Energiecockpit» («Green Cockpit») i, по своєї суті, це комплексний інформаційно-аналітичний інструмент енергетичного контролінгу, який складається 3 апаратного та програмного забезпечення та базується на методах збору, обробки, презентації та складування інформації. У майбутньому очікується, що системи Energiecockpit замінять або суттєво зменшать енергетичну звітність.

19. Аналіз відхилень, як правило, передує управлінню за відхиленнями. У функції контролю акцент робиться на виявленні та аналізі відхилень фактичних величин від запланованих. Тобто недостатньо зафіксувати, наприклад, перевитрату енергетичних ресурсів, треба ще і знайти іiі першопричину, щоб запобігати повторюванню такої ситуації.

20. Енергетичні показники застосовуються спочатку для визначення кількісних цілей використання енергетичних ресурсів, а потім для контролю й аналізу їхнього виконання. Взагалі сфера застосування показників у контролінгу вельми широка, бо втілює в життя його девіз «якщо щось не можна вимірювати, то цим неможливо керувати». Міжнародний стандарт стандарту ISO 50001:2011 потребує використання індикаторів енергоефективності, що можуть представляти собою за рішенням підприємства або показники, або складну економіко-математичну модель. Приклади енергетичних показників: кількість використовуваної енергії за певний період, енергоємність, енергоефективність, енерговіддача, енергооснащеність праці, тощо.

21. Системи показників вважаються більш досконалим та універсальним інструментом контролінгу порівняно із застосуванням окремих показників. Система енергетичних показників має відповідати вимогам інформаційної системи підприємства, може використовуватися для оптимізації споживання енергетичних ресурсів в короткостроковій та довгостроковій перспективі, підтримки планування та контролю на підприємстві. Нині є думка, що системи енергетичних показників варто розробляти або складати індивідуально для кожного підприємства [7, с. 50].

22. Чек-лист є шаблоном, який стандартизує процес виконання завдань та досягнення цілей. Чек-листи широко використовуються в тайм-менеджменті задля запобігання помилкам i форс-мажорним ситуаціям, самоперевірки тощо. Чим вища ціна помилки, тим дієвішим буде використання чек-листів. В енергетичному контролінгу чек-листи слугують цілі підвищення енергоефективності на різних енергетичних об'єктах.
Вони складаються 3 переліку конкретних дій/опцій 3 енергозбереження, використання енергоефективного обладнання тощо, які у сукупності призведуть до більш високого рівня енергоефективності на підприємстві. По мірі проходження чек-листа увага переміщується на ще не виконані опції.

Складання чек-листів може застосовуватися під час планування заходів 3 енергоефективності, але найбільш дієво чек-листи дозволяють проводити незалежний техніко-економічний контроль на різних стадіях управлінського процесу - як під час планування, так і під час реалізації управлінських рішень. Крім того, чек-листи можуть розповсюджуватися серед працівників, як, наприклад, вимоги стандарту 3 енергоменеджменту або енергоефективності, i тоді проводитиметься контроль відповідності вказаним стандартним вимогам.

23. Дью-ділідженс (англ. due diligence - забезпечення належної доброчесності) передбачає ретельну економіко-юридичну підготовку компанії до проведення перетворень, здійснення трансакцій тощо. Все частіше контролінг стали підключати до процедури дью-дідідженс. Особливо це проявляється в фінансовій сфері, але і в енергетичних питаннях має свій потенціал. Енергетичний дью-ділідженс вже активно використовується в практиці західних компаній. Найчастіше його використання пов'язане 3 проектами переходу на нетрадиційні джерела енергії, але й іншим інвестиційним проектам в енергетичній сфері не зашкодить перевірка доброчесності як партнерів, так і самого проекту. Процедура дью-ділідженс має складатися 3 п'яти основних блоків роботи, по кожному 3 яких дається об'єктивний висновок: комерційний або ринковий, податковий, правовий, технічний та екологічний.

Очевидно, що новий погляд на енергетичні проблеми потребує значних перетворень, тому дьюділідженс треба розглядати в енергетичному контролінгу як його консультативну функцію.

24. У практичній діяльності кожного підприємства виникають завдання, вирішення яких потребує виключного підходу, який не можна застосувати для інших завдань. Розмаїття таких ситуаційних підходів об'єднується в світовій практиці в рамках інструменту ad-hoc analysis (від лат. ad hoc - спеціально для цього випадку), тобто вирішення спещіальних завдань. Як правило, саме служба контролінгу долучається до вирішення таких завдань, і очевидно, що така діяльність має відноситися до консультативної функції.

25. Імітаційне або ситуаційне моделювання (англ. simulation modeling) відносять до логіко-математичних методів пізнання складних систем. В економіці імітаційні моделі зазвичай застосовуються для аналізу можливих наслідків прийняття того чи іншого рішення. Серед західних дослідників функціоналу енергетичного контролінгу немає одностайної думки щодо застосування імітаційного моделювання в межах його конкретної функції [4, с. 453; 5, с. 73]. На сучасних вітчизняних підприємствах застосування логіко-математичних методів у енергетичній сфері і зовсім виглядає складним з огляду на необхідність переконувати менеджерів в доцільності вкладання значних грошових коштів та часу дослідників на створення імітаційних 
моделей, їхню перевірку на адекватність і верифікацію. Тому імітаційне моделювання слід віднести до консультативної функції енергетичного контролінгу.

Результати дослідження, проведеного на вітчизняних підприємствах кабельно-провідникової промисловості, щодо використання проаналізованих інструментів енергетичного контролінгу, представлені в наведеній нижче табл. 1. Дослідження виявило слабке застосування інструментів контролінгу задля управління виробничими енергосистемами. Тобто існує чималий резерв підвищення їхньої енергоефективності за рахунок означених функціонально-інструментальних аспектів. 3 таблиці видно, що у практиці управління виробничими енергосистемами зазвичай використовуються функції контролю та інформаційного забезпечення. Проте існують інструменти контролінгу, що спроможні ще більше удосконалити виконання цих функцій.

Аналіз таблиці також доводить, що, незважаючи на наполягання науковців, підприємці не поспішають використовувати консультативні інструменти контролінгу. Невелика кількість проектів (інвестиційних або внутрішньовиробничих) в енергетичній сфері залишила переважно поза увагою функцію координування. Слабо долучаються фахівці енергослужби до планування. Крім того, слід відмітити, що на використання інструментів енергетичного контролінгу впливають розміри підприємства. Тобто чим більшим є підприємство, тим більш значущою $є$ його енергетична служба і тим ширшим є інструментарій, що вона застосовує.

Висновки. Сучасні виклики, щодо ефективності виробничих енергосистем, потребують розширення концептуальних основ контролінгу особливо стосовно його функціонально-інструментального наповнення, бо діяльність, яка базується на філософії контролінгу, здатна впливати на споживання енергоресурсів, енергоефективність, тощо. Проведене дослідження виявило, з одного боку, інтерес господарюючих суб' єктів до інноваційних інструментів управління енергосистемами, а з іншого - використання обмежених інструментів енергетичного контролінгу. Запропонована класифікація інструментарію за функціями енергетичного контролінгу грунтується на конкретних потребах підприємців і розширює міждисциплінарні рамки застосування технічних і економічних заходів для підвищення ефективності діяльності енергетичної служби підприємства.

Подальші дослідження стосуються більш детального розгляду використання кожного 3 наведених інструментів. Особливий інтерес викликає дослідження їхнього мультиплікативного впливу на діяльність підприємства та розрахунок економічного й екологічного ефекту від упровадження енергетичного контролінгу.

Таблиця 1 - Використання інструментів енергетичного контролінгу на підприємствах кабельно-провідникової промисловості станом на 2019 рік

\begin{tabular}{|c|c|c|c|c|}
\hline $\begin{array}{c}\text { Функція } \\
\text { контролінгу }\end{array}$ & Інструменти енергетичного контролінгу & $\begin{array}{c}\text { Великі } \\
\text { підприємства }\end{array}$ & $\begin{array}{c}\text { Середні } \\
\text { підприсмства }\end{array}$ & $\begin{array}{c}\text { Малі } \\
\text { підприсмства }\end{array}$ \\
\hline \multirow[t]{9}{*}{ Планування } & Енергетичний баланс & + & + & + \\
\hline & Картина енергетичних потоків / діаграма Санкей & + & - & - \\
\hline & Графіки енергетичного навантаження & + & + & + \\
\hline & Портфельний аналіз & + & - & - \\
\hline & Аналіз енергетичного ринку & - & - & - \\
\hline & Бенчмаркінг & - & - & - \\
\hline & Аналіз ризиків & - & - & - \\
\hline & Інвестиційні розрахунки & $+/-$ & - & - \\
\hline & Морфологічний аналіз & $+/-$ & - & - \\
\hline \multirow[t]{3}{*}{ Координування } & Плани реалізації проектів / діаграма Ганта & - & - & - \\
\hline & Управління за відхиленнями & + & - & - \\
\hline & Аналіз динаміки енергетичних витрат & + & - & - \\
\hline \multirow{6}{*}{$\begin{array}{l}\text { Інформаційне } \\
\text { забезпечення }\end{array}$} & Енергетичній облік & + & + & + \\
\hline & Розрахунок енергетичних витрат & + & + & - \\
\hline & Внутрішньо виробничий енергетичний розрахунок & + & $+/-$ & - \\
\hline & Розрахунок витрат за процесами & + & $+/-$ & - \\
\hline & Енергетична звітність & + & + & + \\
\hline & Спеціальні програмні продукти & $+/-$ & + & - \\
\hline \multirow[t]{4}{*}{ Контроль } & Аналіз відхилень & + & $+/-$ & $+/-$ \\
\hline & Енергетичні показники & + & $+/-$ & + \\
\hline & Система енергетичних показників & + & $+/-$ & - \\
\hline & Чек листи & - & - & - \\
\hline \multirow[t]{3}{*}{ Консультування } & Дью-ділідженс & - & - & - \\
\hline & Вирішення спеціальних задач / Ad-hoc analysis & - & - & - \\
\hline & Імітаційне моделювання & - & - & - \\
\hline
\end{tabular}

«+» використовується

«-» не використовується

«+/-» використовується частково 


\section{Список використаних джерел:}

1. Дзядикевич Ю.В., Буряк М.В., Розум Р.І. Енергетичний менеджмент. Тернопіль: Економічна думка. 2010. 295 с.

2. Денисюк С.П. Теоретичні основи побудови систем енергетичного менеджменту в Україні. Енергетика: економіка, технології, екологія. 2015. № 1. С. 7-17.

3. Сотник I.М. Ефективний енергоменеджмент: теоретичні основи фінансової діяльності енергосервісних компаній. Маркетинг і менеджмент інновацій. 2015. № 3. С. 212-225.

4. Matzen F.J.; R. Tesch. Industrielle Energiestrategie: Praxishandbuch für Entscheider des produzierenden Gewerbes. Wiesbaden. Springer Fachmedien Wiesbaden : Imprint: Springer Gabler. 2017. $823 \mathrm{~s}$.

5. Gleich R. Schulze, M. Energiecontrolling: Konzeption und Umsetzung in der Praxis. Controller Magazin. 2014. № 39(4). S. 71-75.

6. Zumpe S. Energiecontrolling als Bestandteil des Energiemanagements. Energiecontrolling: Energiekosten systematisch steuern und senken. Hrsg. Ronald Gleich. München: Heufer-Lexware GmbH \& Co.KG. 2014. S. 127-138.

7. Hessel V. Energiekennzahlen als Grundlage des Energiecontrollings Energiecontrolling: Energiekosten systematisch steuern und senken. Hrsg. Ronald Gleich. München: Heufer-Lexware GmbH \& Co.KG. 2014. S. 43-59.

\section{References:}

1. Dzyadykevych Y.V., Buryak M.V., Rozum R.I. (2010). Energetychniy menedghment [Energy management]. Ternopil: Economichna dumka, $295 \mathrm{p}$

2. Denisyuk S.P., Borychenko O.V. (2015).Teoretychni osnovy pobudovy system energetychnogo menedghmentu v Ukraini [Theoretical basis for design of energy management system in Ukraine]. Energetyka: economica, tekhnologii, ekologiya, № 1, pp. 7-17.

3. Sotnyk I.M., Kulyk L.A. (2015). Effektyvniy energomenedghment: teoretychni osnovy finansovoy diyalnosti energoservisnykh kompaniy [Efficient energy management: theoretical basis for financial activity of energy service companies]. Marketing i menedghment innovaziy. № 3. pp. 212-225

4. Matzen F.J., Tesch R. (2017). Industrielle Energiestrategie: Praxishandbuch für Entscheider des produzierenden Gewerbes, Wiesbaden: Springer Fachmedien Wiesbaden: Imprint: Springer Gabler. $823 \mathrm{~s}$.

5. Gleich, R., Schulze, M. (2014). Energiecontrolling: Konzeption und Umsetzung in der Praxis. Controller Magazin. No 39(4). S. 71-75.

6. Zumpe S. (2014). Energiecontrolling als Bestandteil des Energiemanagements. In Energiecontrolling: Energiekosten systematisch steuern und senken. Hrsg. Ronald Gleich. München: Heufer-Lexware GmbH \& Co.KG, 127-138.

7. Hessel V. (2014). Energiekennzahlen als Grundlage des Energiecontrollings. In Energiecontrolling: Energiekosten systematisch steuern und senken. Hrsg. Ronald Gleich. München: Heufer-Lexware GmbH \& Co.KG, 43-59.

Degtiareva Olga

Odessa National Economic University

\section{CLASSIFICATION AND ANALYSIS \\ OF MODERN CONTROLLING INSTRUMENTS FOR ENHANCEMENT OF EFFICIENCY OF INDUSTRIAL ENERGY SYSTEMS}

The paper is to classify instruments of energy controlling according to its functions and to demonstrate how they affect energy performance on industrial enterprises. The study covers development of new direction of the controlling concept called energy controlling. The focus was given to functional and instrumental aspects of energy controlling. Main questions of the research are: what tasks can be solved by application of energy controlling and what tools there are to respond the challenges in the energy sector of industrial enterprise. According to the proposed classification there were determined functions of energy controlling accompanied by sets of instruments to fulfill in practice each of them. Thus, controlling instruments to actualize the function of energy planning are: energy balance, Sankey Diagram for illustration of energy flows, charts of energy loading, portfolio analysis, analysis of energy market, benchmarking, risk analysis, investment calculations, and morphological analysis. The function of coordination is a symbiosis of planning, realization and control of managerial decisions. In energy controlling there are following instruments to do it: Gantt chart, milestones analysis, analysis of energy costs trends, status reporting. Instruments of information function are energy accounting, energy costing, internal energy accounting, activity-based-costing, energy reporting, and special hardware and software tools. The function of control needs deviation analysis as a part of deviation management, separated indexes or systemically joined indexed (e.g. BSC), check lists. Instruments of consulting function are due diligence, ad-hoc analysis and simulation modeling. The proposed theoretical and practical approach opens a wide perspective for enhancement of energy performance in enterprises. The variety of tools proposed was qualified according to functions of energy controlling and described according to expected results and objectives to use. The research revealed, on one hand, there is a big interest for innovative tools to manage energy system, but on another hand, manufacturing enterprises use very limited tools of energy controlling. That's why further research should focus as on usage of separate instruments of energy controlling as on their multiplicative impact and calculations of economical and ecological effect of energy controlling use.

Key words: energy controlling, functions of controlling, instruments of controlling, energy performance, manufacturing enterprise.

JEL classification: L23, M11, Q43 